\title{
The effect of therapeutic exercise in the prevention of lymphoedema secondary to breast cancer: a systematic review
}

\author{
Laura Tendero-Ruiz, Rocío Palomo-Carrión, Álvaro Megía-García-Carpintero, \\ Soraya Pérez-Nombela, Purificación López-Muñoz, Elisabeth Bravo-Esteban
}

Department of Nursing, Physiotherapy and Occupational Therapy, Castilla La-Mancha University, Toledo, Spain

Submitted: 26 September 2020

Accepted: 4 November 2020

Arch Med Sci

DOI: https://doi.org/10.5114/aoms.2020.101435

Copyright $\odot 2020$ Termedia \& Banach

\section{Abstract}

Introduction: One of the most frequent complications of breast cancer treatment is lymphoedema (LE), with lymphadenectomy and radiotherapy being the main triggers of this pathology in developed countries. The aim of the study was to determine the efficacy of therapeutic exercise in the prevention of upper limb (UL) lymphoedema evaluated through cirtometry, volumetry, or bioimpedance spectroscopy (BIS) in women after breast cancer removal surgery.

Material and methods: The Pubmed, PEDro, and Cochrane databases were consulted up to May 2020, including randomised clinical trials (RCTs) on therapeutic physical exercise as a possible preventive measure against breast cancer-related lymphoedema (BCRL). The studies were requested to have participants with UL lymphoedema and a control group.

Results: A total of 304 articles were found, of which 9 were included (standalone studies). A therapeutic exercise program (strength and/or aerobic training) in women who had been surgically intervened for breast cancer may prevent lymphedema, compared to a regular care.

Conclusions: A therapeutic exercise program (strength and/or aerobic training) in women operated on for breast cancer contributes to reducing the number of cases that could obtain a greater difference in volume in their upper limbs, compared to a regular care program. However, further research is necessary to affirm that therapeutic physical exercise prevents BCRL.

Key words: breast cancer lymphoedema, exercise therapy, public health, quality of life, secondary prevention.

\section{Introduction}

Breast cancer is one of the most frequent cancers and the most typical in women worldwide, and it is increasing especially in developed countries. Its incidence changes widely throughout the world, with rates as high as 99.4 per 100,000 in North America [1]. It is estimated that one in eight women is at risk of developing it during her lifetime, with a survival rate above $90 \%$ at 5 years and significant morbidity after the treatment $[2,3]$. One of the most weakening complications of the breast cancer treatment is lymphoedema (LE) [4, 5], with lymphadenectomy and radiotherapy being the main triggers of this pathology in developed

\author{
Corresponding author: \\ Prof. Rocío Palomo-Carrión \\ Department of Nursing, \\ Physiotherapy \\ and Occupational Therapy \\ Castilla La-Mancha \\ University \\ Toledo, Spain \\ E-mail: Rocio.Palomo@uclm.es
}


countries [6]. The published data about the rate of $L E$ are very dissimilar, ranging between $2 \%$ and $94 \%[4,7,8]$. DiSipio et al. (2013), in their systematic review and meta-analysis, estimated that the probability of developing arm lymphoedema is 21.4\% (95\% Cl: 14.9-29.8\%) [9].

Lymphoedema is defined as an accumulation of protein-rich fluid in interstitial tissues as a result of the alteration of the lymphatic function $[5,9]$. It can have a negative effect on the performance of different activities of daily living, with a significant physical, functional, psychological, and economic impact on the people who suffer from it $[4,6,9-11]$. Therapeutic physical exercise can contribute to interstitial fluid evacuation, thus reducing the complications and adverse effects of the surgical and adjuvant therapies in breast cancer patients [12-15].

It is a chronic and progressive disease, also disabling in some cases, which requires care and attention throughout life because there is no curative treatment [16], and it is often misdiagnosed, with treatment in late stages or even without applying any therapeutic approach [17]. It is predicted that it will remain a significant problem in the future due to the survival associated with breast cancer as a result of the advances in oncological therapies [6]. Therefore, it is essential to bet on therapeutic physical exercise preventive treatment with the objective of reducing the incidence of this pathology. Cancer is an important cause of mortality worldwide [18]. In addition to the various therapies available, it is important to also focus on the role of modifiable risk factors in cancer prevention and prognosis. According to the World Health Organisation, approximately $35 \%$ of cancer-related deaths can be attributed to these modifiable risk factors, among which obesity (for example hospital malnutrition due to poor patient control can contribute to weight alteration [19]) and lack of physical activity play prominent roles [20]. Several mechanisms have been proposed for the beneficial effects of physical activity, including decreased levels of reactive oxygen species, enhancement of immune function, decreased levels of inflammation, etc. [21, 22]. Physical activity changes the metabolic profile of oestrogens, leading to reduced hormonal activity and increased anti-proliferative properties in breast cancer patients [23]. Due to the increasing number of individuals diagnosed with cancer, it is important to understand the role of physical activity in cancer prevention and therapy. The benefits of physical activity in cancer patients are multifaceted; they have been observed in cancer prevention, mortality, and quality of life [24]. Thus, the majority of studies included exercise as a therapy to decrease BCRL symptoms; however, few studies suggest a preventive approach to the disease [18-25]. Based on the obvious need to develop preventive measures, the aim of the present review was to determine the efficacy of therapeutic exercise in the prevention of lymphoedema evaluated through cirtometry, volumetry, or bioimpedance spectroscopy (BIS) of the upper limb (UL) in women after breast cancer removal surgery.

\section{Material and methods}

The methodology was guided by Preferred Reporting Items for Systematic reviews and Meta-Analyses (PRISMA) [26].

\section{Search strategy}

The PubMed, PEDro, and Cochrane databases were consulted from the date they were created to May $9^{\text {th }} 2020$, with the aim of finding studies that included therapeutic exercise as a preventive method against BCRL. The MeSH terms used were: "breast cancer lymphedema", "exercise therapy", and "exercise". Moreover, other terms were also used: ("lymphedema" OR "breast cancer-related lymphedema”) AND ("therapeutic exercise” OR "physical activity" OR "aerobic training" OR "resistance training" OR "strength training" OR "strength") AND ("preventive therapy" OR "prevention"). The search was replicated by two researchers. There was consensus in the searches of both researchers.

\section{Inclusion and exclusion criteria}

The authors selected randomised clinical trials (RCTs), published in English or Spanish, that included women intervened for breast cancer (surgery with conservation of the breast or mastectomy) and treated with therapeutic exercise with a preventive approach against the complications derived from the surgery or other treatments (radiotherapy and/or chemotherapy). Understanding therapeutic exercise as strength and/or aerobic training, these clinical trials could include women with or without the risk of developing lymphoedema. Furthermore, this review only included trials that had a control group and used UL oedema evaluated by cirtometry, volumetry, or BIS as a dependent variable. The authors excluded clinical trials in which the participants had been diagnosed with unilateral or bilateral lymphoedema prior to or during the treatment, as well as the articles that had fewer than 20 individuals per group and those with an intervention programme shorter than two months.

\section{Study selection}

Firstly, the repeated articles from the different databases consulted were discarded. Then, after 
reading the titles and abstracts, the authors excluded the studies that were not related to the specific topic tackled in this review and those that did not meet the established inclusion criteria. Lastly, the complete text of the rest of the articles was read, and the most relevant trials were selected to compose the sample of this systematic review.

\section{Evaluation of the methodological quality}

To assess the methodology and internal validity of the selected trials, the PEDro scale was used, which is based on the Delphi method developed by Verhagen et al. (1998) [27, 28]. This scale consists of 11 criteria with two possible answers ("yes" or "no"), and each of them contributes one point to the total score (minimum to maximum score range: 0-10 points), except the first criterion, which evaluates the external validity. According to Moseley et al. (1999), studies with a score above 5 points are considered to have a high methodological quality, whereas those with a score of 4 or 5 points have a moderate methodological quality, and those with a score of 3 points or less are of low methodological quality [29].

\section{Results}

A total of 304 articles were found in the PubMed, PEDro, and Cochrane databases. Of these, 75 were discarded for being repeated, and of the remaining 229, 173 articles were discarded after reading the title and/or abstract, because they did not use therapeutic exercise as a preventive method against lymphoedema in women who had breast cancer removal surgery. Moreover, another 47 articles were discarded based on the fact that they did not meet the inclusion criteria. The main criteria for the exclusion of these articles were as follows: 1) the inclusion of women diagnosed with unilateral or bilateral lymphoedema and 2) the absence of a control group. Nine potentially relevant articles (stand-alone studies) were selected for systematic review after reading the complete text (Figure 1).

\section{Methodological quality of the studies}

Table I shows the results of the evaluation of the methodological quality of the studies included in this review. Most of the RCTs were considered of high methodological quality, obtaining more than $5 / 10$ points in the PEDro scale, with two of them scoring $6 / 10[30,31]$, three scoring $7 / 10[2$, 8, 32], and another three scoring 8/10 [7, 33, 34]; there was one [35] that was considered to have moderate methodological quality, with a score of $5 / 10$.

However, several criteria must be highlighted. Random and blind allocation was applied in eight [2, 7, 8, 30-34] and six [2, 7, 8, 32-34] studies, respectively. In all trials, the evaluators who measured at least one key result were blinded, although due to the difficulty of blinding all the subjects and/or therapists in this type of research, only one article was defined as double-blind, i.e. both the participants and the therapists were blinded [34], and in another study [2] the authors managed to blind the therapists who administered the therapy. Regarding the follow-up, in only
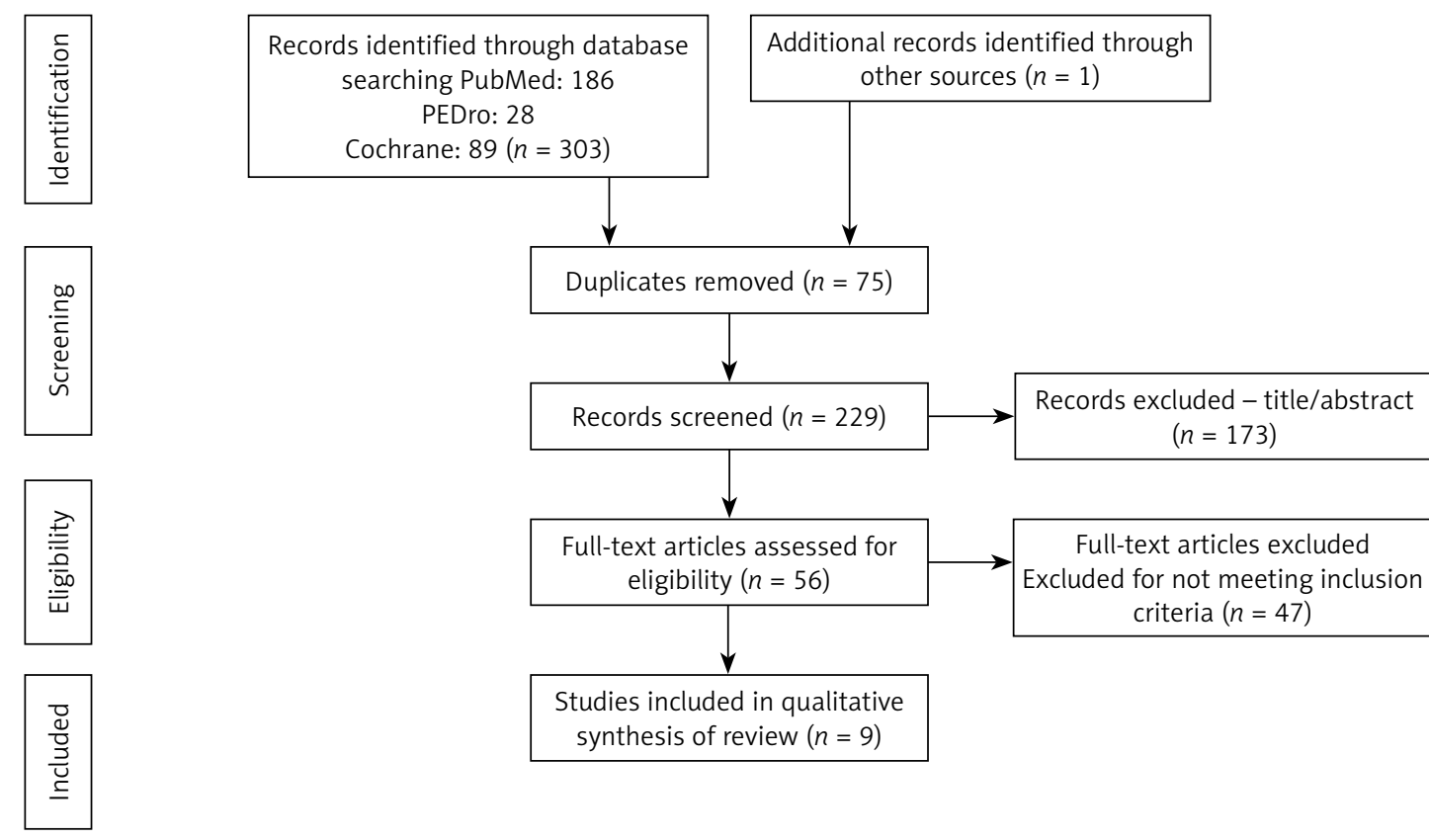

Figure 1. PRISMA flow chart 
Table I. Evaluation of the methodological quality of articles based on the PEDro scale. 1 - Selection criteria, 2 - random allocation, 3 - blind allocation, 4 - baseline characteristics of the groups, 5 - blinded individuals, 6 - blinded therapists, 7 - blinded evaluators, 8 - follow-up, 9 - intention to treat, 10 - analysis between groups, 11 - score or variability estimation

\begin{tabular}{|c|c|c|c|c|c|c|c|c|c|c|c|c|}
\hline \multirow[t]{2}{*}{ Authors/year } & \multicolumn{11}{|c|}{ Evaluation criteria } & \multirow[t]{2}{*}{ Total score } \\
\hline & 1 & 2 & 3 & 4 & 5 & 6 & 7 & 8 & 9 & 10 & 11 & \\
\hline $\begin{array}{l}\text { Basen-Engquist } \\
\text { et al., } 2006 \text { [30] }\end{array}$ & Yes & Yes & No & Yes & No & No & Yes & No & Yes & Yes & Yes & $6 / 10$ \\
\hline $\begin{array}{l}\text { Sagen et al., } \\
2009 \text { [32] }\end{array}$ & Yes & Yes & Yes & Yes & No & No & Yes & No & Yes & Yes & Yes & $7 / 10$ \\
\hline $\begin{array}{l}\text { Schmitz et al., } \\
2010 \text { [7] }\end{array}$ & Yes & Yes & Yes & Yes & No & No & Yes & Yes & Yes & Yes & Yes & $8 / 10$ \\
\hline $\begin{array}{l}\text { Fernández-Lao } \\
\text { et al., } 2012 \text { [35] }\end{array}$ & Yes & No & No & Yes & No & No & Yes & No & Yes & Yes & Yes & $5 / 10$ \\
\hline $\begin{array}{l}\text { Kilbreath et al., } \\
2012 \text { [33] }\end{array}$ & Yes & Yes & Yes & Yes & No & No & Yes & Yes & Yes & Yes & Yes & $8 / 10$ \\
\hline $\begin{array}{l}\text { Anderson et al., } \\
2012[34]\end{array}$ & Yes & Yes & Yes & Yes & Yes & Yes & Yes & No & No & Yes & Yes & $8 / 10$ \\
\hline $\begin{array}{l}\text { Kilbreath et al., } \\
2013 \text { [31] }\end{array}$ & Yes & Yes & No & Yes & No & No & Yes & Yes & No & Yes & Yes & $6 / 10$ \\
\hline $\begin{array}{l}\text { Schmidt et al., } \\
2017 \text { [2] }\end{array}$ & Yes & Yes & Yes & Yes & No & Yes & Yes & No & No & Yes & Yes & $7 / 10$ \\
\hline $\begin{array}{l}\text { Ammitzbøll } \\
\text { et al., } 2019 \text { [8] }\end{array}$ & Yes & Yes & Yes & Yes & No & No & Yes & No & Yes & Yes & Yes & $7 / 10$ \\
\hline
\end{tabular}

three studies [7, 31, 33] the measurement of at least one key result was obtained from over $85 \%$ of the participants that were initially allocated to the groups, and in six trials [7, 8, 30, 32, 35], the results were analysed by intention to treat (ITT).

\section{Characteristics of the studies}

The characteristics of the studies included in this systematic review are shown in Table II. Nine RCTs published between 2006 and 2019 were included, with a total of 1147 patients distributed in groups of 21-104 women. The selected articles evaluated the effect of therapeutic strength $[2,7$, $8,31-34]$ or aerobic $[2,30,34,36]$ exercise on the swelling of the affected upper limb in women who had been surgically intervened for breast cancer; three of these articles also included stretching exercises in their intervention programmes [31, 33, 34]. Strength training was understood as exercises with weights, dumbbells, variable-resistance machines, and thera-bands, whereas aerobic training was understood as activities such as walking; on the other hand, exercises with hand crank ergometers were considered as combined strength and aerobic training. These trials evaluated the development of BCRL through cirtometry [2, 30, 33, 35], water displacement volumetry [7, 8, 32, 34], or BIS $[31,33]$. Moreover, it was considered fundamental that these articles included a control group to compare the effects of therapeutic exercise with the habitual care (patient education) of the affected arm in these patients.
Of the articles included in this review, two were based on an aerobic training programme in the intervention group $[30,35]$, three on a strength training programme $[7,8,32]$, one on a combined strength and aerobic training programme [2], two included stretching exercises in the strength programme [31, 33], and another trial included strength, stretching, and aerobic exercises [34]. The intervention period in the groups ranged between 2 months and 1 year, with an average of 5 months; the number of sessions ranged from one to three per week, with a total average of 50 sessions. All the intervention programmes were initially supervised. Of all the articles, five included women who had completed all the primary treatments for breast cancer [2, 7, 30, 31, 33], two articles included women who received chemotherapy during the study period $[8,34]$, one article included women who had not completed the hormone treatment [35], and another article included women who were receiving chemotherapy, radiotherapy, and/or hormone treatment [32].

\section{Observed effects}

Regarding the results, one study showed a statistically significant decrease in UL volume in both groups [2], two studies reported that the increase in the difference of UL volume was significantly greater in the control group than in the intervention group [7, 31], with one of them demonstrating that the risk of developing lymphoedema was twice as great in the control group [32]. Moreover, 
Table II. Characteristics of the studies

\begin{tabular}{|c|c|c|c|c|c|c|}
\hline Study & Design & Intervention & $\begin{array}{l}\text { Intervention } \\
\text { period }\end{array}$ & Adj T & Follow-up & Results \\
\hline $\begin{array}{l}\text { Basen- } \\
\text { Engquist } \\
\text { et al., } 2006 \\
\text { [30] }\end{array}$ & $\begin{array}{l}\text { IG: } n=35 \\
\text { CG: } n=25\end{array}$ & $\begin{array}{c}1-24 \text { w: } 50^{\prime} \\
\text { cognitive skills }+10^{-} \\
\text {moderate/intense } \\
\text { march }\end{array}$ & $\begin{array}{c}6 \text { months } \\
1-16 \mathrm{w}: 1 \mathrm{ss} / \mathrm{w} ; \\
17-24 \mathrm{w}: 1 \\
\mathrm{ss} / 2 \mathrm{w}\end{array}$ & No & $\begin{array}{l}\mathrm{EV} .1=\text { Pre } \\
\mathrm{EV} .2=6 \\
\text { months } \\
\text { post }\end{array}$ & $\begin{array}{c}\text { ILVD: } \uparrow \text { arm } \\
\text { circumference IG vs. } \\
\text { CG, } p>0.05\end{array}$ \\
\hline $\begin{array}{l}\text { Schmitz } \\
\text { et al., } 2010 \\
\text { [7] }\end{array}$ & $\begin{array}{l}\text { IG: } n=77 \\
\text { CG: } n=77\end{array}$ & $\begin{array}{l}\text { 1-13 w: } 90^{\circ} \mathrm{UL} \text { and } \\
\text { LL S ST (weights and } \\
\text { variable-resistance } \\
\text { machines). } \\
\text { 14-48 w: UST }\end{array}$ & $\begin{array}{c}12 \text { months } \\
1-48 \mathrm{w}: 2 \mathrm{ss} / \mathrm{w}\end{array}$ & No & $\begin{array}{c}\mathrm{EV} .1=\text { Pre } \\
\mathrm{EV} .2=12 \\
\text { months } \\
\text { post }\end{array}$ & $\begin{array}{c}>5 \% \text { ILVD: } 17 \% \text { in } \\
\text { CG and } 11 \% \text { in IG. } \\
{ }^{*} p=0.003 \\
\text { Risk of LE: } 7 \% \text { in IG } \\
\text { and } 22 \% \text { in CG. } \\
{ }^{*} p=0.001\end{array}$ \\
\hline $\begin{array}{l}\text { Fernández- } \\
\text { Lao et al., } \\
2012[35]\end{array}$ & $\begin{array}{c}\text { Aerobic IG: } \\
n=31 \\
\text { Aquatic IG: } \\
n=33 \\
\text { CG: } n=34\end{array}$ & $\begin{array}{c}\text { Aerobic IG: } \\
1-8 \text { w: } 60^{\prime} \text { A ST }\end{array}$ & $\begin{array}{c}2 \text { months } \\
1-8 \mathrm{w}: 3 \mathrm{ss} / \mathrm{w}\end{array}$ & Yes: HT & $\begin{array}{c}\text { EV. } 1=\text { Pre } \\
\text { EV. } 2= \\
\text { Post } \\
\text { EV. } 3=6 \\
\text { months } \\
\text { post }\end{array}$ & $\begin{array}{c}\text { Risk of LE: both IG } \\
<\text { CG } \\
\text { Cirtometry: } \\
\downarrow \text { circumference } \\
\text { aerobic IG > GI } \\
\text { hydrokinesitherapy. } \\
{ }^{*} p=0.019\end{array}$ \\
\hline $\begin{array}{l}\text { Kilbreath } \\
\text { et al., } 2012 \\
{[33]}\end{array}$ & $\begin{array}{l}\text { IG: } n=81 \\
\text { CG: } n=79\end{array}$ & $\begin{array}{l}\text { 1-8 w: S ST } \\
\text { (weights) + } \\
\text { stretching; S UST } \\
\text { (thera-band) + } \\
\text { stretching }\end{array}$ & $\begin{array}{c}2 \text { months } \\
1-8 \text { e: ST } \\
1 \mathrm{ss} / \mathrm{w} \text {; UST } \\
5 \mathrm{ss} / \mathrm{w} \text { stretching } \\
+3 \mathrm{ss} / \mathrm{w} \mathrm{S}\end{array}$ & No & $\begin{array}{c}\text { EV. } 1=\text { Pre } \\
\text { EV. } 2= \\
\text { Post } \\
\text { EV. } 3= \\
6 \text { months } \\
\text { post }\end{array}$ & $\begin{array}{l}\text { Risk of LE: EV. } 2 \text { and } \\
\text { EV.3: } n^{\circ} \text { of women } \\
\text { with LE IG vs. CG, } \\
p>0.05 . \text { EV. } 3 \downarrow n^{\circ} \\
\text { of women with LE in } \\
\text { CG and IG vs. EV.2 }\end{array}$ \\
\hline $\begin{array}{l}\text { Kilbreath } \\
\text { et al., } 2013 \\
\text { [31] }\end{array}$ & $\begin{array}{l}\text { IG: } n=80 \\
\text { CG: } n=80\end{array}$ & $\begin{array}{l}\text { 1-8 w: S ST + } \\
\text { UL stretching + } \\
\text { home UST }\end{array}$ & $\begin{array}{c}2 \text { months } \\
1-8 \mathrm{w}: 1 \mathrm{ss} / \mathrm{w}\end{array}$ & No & $\begin{array}{c}\text { EV. } 1=\text { Pre } \\
\text { EV. } 2= \\
3 \text { months } \\
\text { post } \\
\text { EV. } 3= \\
9 \text { months } \\
\text { post } \\
\text { EV. } 4= \\
15 \text { months } \\
\text { post }\end{array}$ & $\begin{array}{l}\text { Risk of LE: CG over } \\
\text { double the risk of } \\
\text { inflammation than } \\
\text { IG in EV.2. }{ }^{*} p=0.02\end{array}$ \\
\hline $\begin{array}{l}\text { Schmidt } \\
\text { et al., } 2017 \\
{[2]}\end{array}$ & $\begin{array}{l}\text { IG: } n=21 \\
\text { CG: } n=28\end{array}$ & $\begin{array}{l}\text { 1-12 w: 60' S and } \\
\text { A ST (hand crack } \\
\text { ergometer). } \\
\text { 10' warm up + } \\
\text { 25-30'exercise + } \\
5^{\prime} \text { cooling }\end{array}$ & $\begin{array}{c}3 \text { months } \\
1-12 \mathrm{w}: 2 \mathrm{ss} / \mathrm{w}\end{array}$ & No & $\begin{array}{l}\text { EV. } 1=\text { Pre } \\
\text { EV. } 2= \\
3 \text { months } \\
\text { post }\end{array}$ & $\begin{array}{c}\text { Cirtometry: } \downarrow \text { arm } \\
\text { circumference } \\
\text { (wrist, } 15 \mathrm{~cm} \text { over } \\
\text { epicondyle and } \\
\text { elbow) IG and CG; } \\
{ }^{*} p<0.05 . \uparrow \text { armpit } \\
\text { circumference } \\
\text { IG and CG } \\
\left.{ }^{*} p<0.05\right),>\text { in CG } \\
(C G:+10.66 ; \text { IG: } \\
+4.29)\end{array}$ \\
\hline $\begin{array}{l}\text { Sagen } \\
\text { et al., } 2009 \\
{[32]}\end{array}$ & $\begin{array}{l}\text { IG: } n=104 \\
\text { CG: } n=100\end{array}$ & $\begin{array}{c}1-24 \mathrm{w}: 45^{\circ} \text {. No } \\
\text { restriction } A D L+ \\
\text { S ST }\end{array}$ & $\begin{array}{c}6 \text { months } \\
1-24 \mathrm{w}: 2-3 \mathrm{ss} / \mathrm{w}\end{array}$ & $\begin{array}{l}\text { Yes: } \\
\text { CHT, RT } \\
\text { and/or } \\
\text { HT }\end{array}$ & $\begin{array}{c}\text { EV. } 1=\text { Pre } \\
\text { EV. } 2= \\
3 \text { months } \\
\text { post } \\
\text { EV. } 3= \\
6 \text { months } \\
\text { post } \\
\text { EV. } 4= \\
24 \text { months } \\
\text { post }\end{array}$ & $\begin{array}{l}\% \text { patients with LE: } \\
5 \% \text { IG and } 7 \% \text { CG in } \\
\text { EV.2; } 13 \% \text { IG and GC } \\
\text { in EV.4. } p>0.05\end{array}$ \\
\hline
\end{tabular}


Table II. Cont.

\begin{tabular}{|c|c|c|c|c|c|c|}
\hline Study & Design & Intervention & $\begin{array}{l}\text { Intervention } \\
\text { period }\end{array}$ & Adj T & Follow-up & Results \\
\hline $\begin{array}{l}\text { Anderson } \\
\text { et al., } 2012 \\
{[34]}\end{array}$ & $\begin{array}{l}\text { IG: } n=52 \\
\text { CG: } n=52\end{array}$ & $\begin{array}{l}\text { 1-12 w: 60 ' ST. } \\
\text { 5'aerobic warm } \\
\text { up + 30'moderate } \\
\text { march + 20` UL and } \\
\text { LL ST (weights and } \\
\text { variable-resistance } \\
\text { machines) + } \\
5^{\prime} \text { stretching. } \\
\text { Exercises to } \\
\text { favour lymphatic } \\
\text { flow + breathing } \\
\text { techniques }\end{array}$ & $\begin{array}{c}3 \text { months } \\
1-12 \mathrm{w}: 2 \mathrm{ss} / \mathrm{w}\end{array}$ & Yes: CHT & $\begin{array}{c}\text { EV. } 1=\text { Pre } \\
\text { EV. } 2= \\
3 \text { months } \\
\text { post } \\
\text { EV. } 3= \\
6 \text { months } \\
\text { post } \\
\text { EV. } 4= \\
9 \text { months } \\
\text { post } \\
\text { EV. } 5= \\
12 \text { months } \\
\text { post } \\
\text { EV. } 6= \\
18 \text { months } \\
\text { post }\end{array}$ & $\begin{array}{c}\text { Adjusted mean } \\
\text { volume change } \\
\text { (ANCOVA): } 33.5 \mathrm{~m} \\
\text { in IG vs. } 60.4 \mathrm{ml} \text { in } \\
\text { CG. } p=0.54\end{array}$ \\
\hline $\begin{array}{l}\text { Ammitzbøll } \\
\text { et al., } 2019 \\
\text { [8] }\end{array}$ & $\begin{array}{l}\text { IG: } n=82 \\
\text { CG: } n=76\end{array}$ & $\begin{array}{c}1-20 \mathrm{w}: \mathrm{ST} \\
20-50 \mathrm{~s}: \mathrm{UST} \\
1-50 \mathrm{w}: \mathrm{UL}, \mathrm{LL} \text { and } \\
\text { core } \mathrm{S} \text { (dumbbells } \\
\text { and thera-band) }\end{array}$ & $\begin{array}{c}12 \text { months } \\
\text { and } 2 \text { weeks } \\
1-20 \text { w: ST } \\
2 \text { ss/w; UST } 1 \text { ss/w } \\
21-5 \text { ws: } 3 \text { ss/w }\end{array}$ & Yes: CHT & $\begin{array}{c}\text { EV. } 1=\text { Pre } \\
\text { EV. } 2= \\
12 \text { months } \\
\text { post }\end{array}$ & $\begin{array}{l}\text { ILVD: difference IG } \\
\text { vs. CG. } p>0.05\end{array}$ \\
\hline
\end{tabular}

Aerobic training - Adj T adjuvant treatment, ADL - activities of daily living, CG - control group, CHT - chemotherapy, EV - evaluation, $H T$ - hormone therapy, IG - intervention group, ILVD - interlimb volume difference, $L E$ - lymphedema, $L L$ - lower limb, $R T$ - radiotherapy, $S$ - strength training, SS/W - sessions/week, ST - supervised training, UL - upper limb, UST - unsupervised training, $w-w e e k .{ }^{*} p<0.05$ - statistically significant differences.

another clinical trial showed that the group of the therapeutic exercise performed on a surface (aerobic exercise) and the aquatic therapeutic exercise group had lower probability of developing an increase of UL inflammation than the control group, with the decrease in UL circumference being statistically significantly greater in the aerobic exercise group than in the aquatic exercise group [35]. The other five studies do not show a statistically significant difference in the number of women with lymphoedema secondary to breast cancer [8, 30, 32-34], although two of them show that the difference in volume between limbs was greater in the control group than in the intervention group [32, 34].

Furthermore, the therapeutic exercise also showed positive effects on the quality of life [2, 30, 34, 35], body composition (weight, body mass index (BMI), fat mass, and lean mass) [7, 35], physical performance and fatigue [2, 34], amplitude of the range of motion of the shoulder of the affected side [8, 33], and muscular strength of the upper limb [2, 8, 33].

\section{Discussion}

The aim of this systematic review was to determine the efficacy of therapeutic exercise to prevent BCRL evaluated through cirtometry, volumetry, or BIS. Of the nine articles included, five demonstrate that the proportion of women who presented a greater difference in UL volume was lower in the intervention group than in the control group [7, 31, 32, 34, 35], with the results of two of these trials being statistically significant [7, 31].

In the field of lymphoedema treatment in female breast cancer survivors, there are several research works in which the benefits of exercise treatment in reducing lymphoedema have been collected [36-39]. In the studies of DiSipo et al. [9] and Baumann et al. [25] subjective improvements in the quality of life of the patients, anxiety (as occurs in other pathologies that alter the quality of life $[40,41])$, the decrease in lymphoedema (evaluated with volumetry) and, equally important, the non-appearance of adverse effects in the study population, are revealed. However, to date, there is no review that focuses on the importance of exercise work in preventing the onset of lymphoedema [9, 25].

Traditionally, physicians have recommended that cancer patients avoid physical activity; however, research on therapeutic exercise opposes such a line of thought. With the aim of finding an answer to this controversy of ideas, the American College of Sports Medicine (ACSM) concluded that physical training is safe during and after cancer treatment, so long as the training programme is adapted to the needs of each patient and controlled by a qualified professional to avoid complications [42]. According to Schmitz (2010), the use of the affected upper limb in activities of daily living involves a slight decrease in the risk of developing or worsening lymphoedema, thus 
suggesting an improvement of the motor function and quality of life [10]. Moreover, this author also states that progressive training can be more protective than the inevitable muscle atrophy that results from the restriction of activity of the affected UL. In this sense, it is suggested that physical activity can reduce the complications and secondary effects of surgical and adjuvant therapies in breast cancer survivors [13-15, 32, 43]. Baumann et al. (2018) demonstrated that physical exercise can improve the state of BCRL, so long as the training is initiated with supervision and individually adapted based on the response of the symptoms of each patient [25].

Mobilisation of the lymph in the body occurs through intrinsic and extrinsic mechanisms; one of the extrinsic factors is muscle contraction, i.e. the cyclic compression/expansion of the action of the surrounding muscle tissue [12]. Experimental evidence suggests that aerobic exercise can increase the lymphatic function, because it decreases inflammation of the subcutaneous tissue, thus reducing inflammation of the lymphatic vessels [6]. Regarding progressive strength training, it is considered that the controlled physiological stress caused by this type of exercise increases the maximum working capacity of the affected arm, thus reducing the effort required to perform activities of daily living, such as lifting objects, thereby protecting it from lesions or inflammatory responses [7, 10]. Furthermore, both aerobic exercise and strength training cause changes in body composition; therefore, they could reduce the risk of developing lymphoedema, because obesity and weight gain after surgery are considered as risk factors of great influence on the development of secondary lymphoedema [44].

With respect to the duration of the intervention programme, it could be asserted that a minimum of two months is required to obtain positive results in terms of LE development. Kilbreath et al. (2013) observed that the women who completed a 2-month strength training programme showed a lower risk of developing lymphoedema than women in a control group [31]. Moreover, the clinical trials included in this review demonstrate that it is safe to initiate a therapeutic exercise programme shortly after breast cancer removal surgery, because none of them reported adverse effects on the development of oedema in the affected UL, although it is recommended that the exercise be initiated once the drainage is removed [45]. These studies highlight the importance of conducting an initially supervised, progressive, and individualised intervention programme, based on either strength and/or aerobic training with self-management for the patient.

The main limitation we found in the realisation of this review was the small number of articles available; there are more articles that apply therapeutic physical exercise as a treatment for BCRL [25], although very few of them include women without a previous diagnosis of lymphoedema approaching exercise as a possible preventive measure. Therefore, it is a concept that requires further research, and thus it would be interesting to study its effects separately in women with and without adjuvant treatment, to prevent the results from being influenced by possible effects of this treatment. However, in this review it was not possible to include only clinical trials of women who had completed the primary treatment for breast cancer (radiotherapy, chemotherapy, and/or hormone treatment), due to the small number of articles available. Another limitation of this review was the fact that each article has its particular characteristics, and there are several risk factors for the development of secondary lymphoedema, such as radiotherapy, chemotherapy with taxanes, obesity, the number of lymph nodes removed, the time that the surgical drainage is maintained, seroma, and surgical wound infections.

Regarding its strengths, this systematic review includes articles of high and moderate methodological quality that back the safety and benefits of therapeutic exercise in women who have been surgically intervened for breast cancer, and the references included are relevant and current. Also, this review identifies a significant lack of research on lymphoedema prevention, and this research provides different strategies for it, being relevant to the study problem. This review may change the therapeutic approach of women undergoing treatment for breast cancer, so that it can have an important physical, mental, and social impact, improving the life quality of these patients.

In conclusion, the results of the present systematic review show that therapeutic exercise in women who had been surgically intervened for breast cancer may prevent lymphoedema, compared to a conventional care programme, and it could be an empowerment tool for women with breast cancer. However, further research is necessary to affirm that therapeutic physical exercise prevents BCRL.

\section{Conflict of interest}

The authors declare no conflict of interest.

\section{References}

1. Who.int. Breast cancer: prevention and control [Internet]. 2020 [cited 13 October 2020]. Available from: https://www.who.int/topics/cancer/breastcancer/en/

2. Schmidt T, Berner J, Jonat W, et al. Influence of arm crank ergometry on development of lymphoedema in breast cancer patients after axillary dissection: a randomized controlled trail. J Rehabil Med 2017; 49: 78-83. 
3. Aecc.es. Pronóstico del Cáncer de Mama: Mortalidad y Esperanza de vida [sede Web]. 2018 [actualizada 2019; acceso 24 Abril 2020]. Disponible en: https://www.aecc. es/es/todo-sobre-cancer/tipos-cancer/cancer-mama/ mas-informacion/evolucion-cancer-mama

4. Hayes SC, Janda M, Cornish B, Battistutta D, Newman B. Lymphedema after breast cancer: incidence, risk factors, and effect on upper body function. J Clin Oncol 2008; 26: 3536-42.

5. Cormier JN, Askew RL, Mungovan KS, Xing Y, Ross MI, Armer JM. Lymphedema beyond breast cancer: a systematic review and meta-analysis of cancer-related secondary lymphedema. Cancer 2010; 116: 5138-49.

6. Dayan JH, Ly CL, Kataru RP, Mehrara BJ. Lymphedema: pathogenesis and novel therapies. Annu Rev Med 2018; 69: 263-76.

7. Schmitz KH, Ahmed RL, Troxel AB, et al. Weight trial. JAMA 2010; 304: 2699-705.

8. Ammitzbøll G, Johansen C, Lanng C, et al. Progressive resistance training to prevent arm lymphedema in the first year after breast cancer surgery: results of a randomized controlled trial. Cancer 2019; 125: 1683-92.

9. DiSipio T, Rye S, Newman B, Hayes S. Incidence of unilateral arm lymphoedema after breast cancer: a systematic review and meta-analysis. Lancet Oncol 2013; 14: 500-15.

10. Schmitz KH. Balancing lymphedema risk: exercise versus deconditioning for breast cancer survivors. Exerc Sport Sci Rev 2010; 38: 17-24.

11. Stanton AW, Modi S, Mellor RH, Levick JR, Mortimer PS. Recent advances in breast cancer-related lymphedema of the arm: lymphatic pump failure and predisposing factors. Lymphat Res Biol 2009; 7: 29-45.

12. Zawieja D. Lymphatic biology and the microcirculation: past, present and future. Microcirculation 2005; 12 141-50.

13. Courneya KS, Segal RJ, Mackey JR, et al. Effects of aerobic and resistance exercise in breast cancer patients receiving adjuvant chemotherapy: a multicenter randomized controlled trial. J Clin Oncol 2007; 25: 4396-404.

14. Daley AJ, Crank H, Saxton JM, Mutrie N, Coleman R, Roalfe $A$. Randomized trial of exercise therapy in women treated for breast cancer. J Clin Oncol 2007; 25: 1713-21.

15. Milne HM, Wallman KE, Gordon S, Curneya KS. Impact of a combined resistance and aerobic exercise program on motivational variables in breast cancer survivors: a randomized controlled trial. Ann Behav Med 2008; 36: 158-66.

16. International Society of Lymphology. The diagnosis and treatment of peripheral lymphedema: 2013 Consensus Document of the International Society of Lymphology. Lymphology 2013; 46: 1-11.

17. Szuba A, Shin WS, Strauss HW, Rockson S. The Third Circulation: radionuclide lymphoscintigraphy in the evaluation of lymphedema. J Nucl Med 2003; 44: 43-57.

18. Jemal A, Bray F, Center MM, et al. Global cancer statistics. CA Cancer J Clin 2011; 61: 69-90.

19. Suárez-Llanos JP, Vallejo-Torres L, García-Bello MÁ, et al. Cost-effectiveness of the hospital nutrition screening tool CIPA. Arch Med Sci 2019; 16: 273-81.

20. Danaei G, Vander Hoorn S, Lopez AD, et al. Causes of cancer in the world: Comparative risk assessment of nine behavioral and environmental risk factors. Lancet 2005; 366: 1784-93.

21. Marzatico F, Pansarasa O, Bertorelli L, et al. Blood free radical antioxidant enzymes and lipid peroxides following long-distance and lactacidemic performances in highly trained aerobic and sprint athletes. J Sports Med Phys Fitness 1997; 37: 235-9.

22. Bradley RL, Jeon JY, Liu FF, et al. Voluntary exercise im proves insulin sensitivity and adipose tissue inflammation in diet-induced obese mice. Am J Physiol Endocrinol Metab 2008; 295: 586-94.

23. Zhu BT, Conney AH. Functional role of estrogen metabolism in target cells: review and perspectives. Carcinogenesis 1998; 19: 1-27.

24. Kushi LH, Doyle C, McCullough M, et al. American Cancer Society Guidelines on nutrition and physical activity for cancer prevention: reducing the risk of cancer with healthy food choices and physical activity. CA Cancer J Clin 2012; 62: 30-67.

25. Baumann FT, Reike A, Reimer V, et al. Effects of physical exercise on breast cancer-related secondary lymphedema: a systematic review. Breast Cancer Res Treat 2018; 170: 1-13.

26. Liberati A, Altman DG, Tetzla J, et al. The PRISMA statement for reporting systematic reviews and meta-analyses of studies that evaluate healthcare interventions: explanation and elaboration. BMJ 2009; 339: b2700.

27. Sherrington C, Herbert RD, Maher CG, Moseley AM. PEDro. A database of randomized trials and systematic reviews in physiotherapy. Man Ther 2000; 5: 223-6.

28. Verhagen AP, De Vet HC, De Bie RA, et al. The Delphi list: a criteria list for quality assessment of randomized clinical trials for conducting systematic reviews developed by Delphi consensus. J Clin Epidemiol 1998; 51: 1235-41.

29. Roig M, Shadgan B, Reid WD. Eccentric exercise in patients with chronic health conditions: a systematic review. Physiother Can 2008; 60: 146-60.

30. Basen-Engquist K, Taylor CL, Rosenblum C, et al. Randomized pilot test of a lifestyle physical activity intervention for breast cancer survivors. Patient Educ Couns 2006; 64: 225-34.

31. Kilbreath SL, Lee MJ, Refshauge KM, et al. Transient swelling versus lymphoedema in the first year following surgery for breast cancer. Support Care Cancer 2013; 21: 2207-15.

32. Sagen A, Karesen R, Risberg MA. Physical activity for the affected limb and arm lymphedema after breast cancer surgery. A prospective, randomized controlled trial with two years follow-up. Acta Oncol 2009; 48: 1102-10.

33. Kilbreath SL, Refshauge KM, Beith JM, et al. Upper limb progressive resistance training and stretching exercises following surgery for early breast cancer: a randomized controlled trial. Breast Cancer Res Treat 2012; 133: 667-76.

34. Anderson RT, Kimmick GG, Mccoy TP, et al. A randomized trial of exercise on well-being and function following breast cancer surgery: the RESTORE trial. J Cancer Surviv 2012; 6: 172-81.

35. Fernández-Lao C, Cantarero-Villanueva I, Ariza-García A, Fernández-de-las-Peñas C, Arroyo-Morales M. Water versus land-based multimodal exercise program effects on body composition in breast cancer survivors: a controlled clinical trial. Support Care Cancer 2013; 21: 521-30.

36. He L, Qu H, Wu Q, Song Y. Lymphedema in survivors of breast cancer. Oncol Lett 2020; 19: 2085-96.

37. Kim S, Han J, Lee MY, Jang MK. The experience of cancer-related fatigue, exercise and exercise adherence among women breast cancer survivors: insights from focus group interviews. J Clin Nurs 2020; 29: 758-69.

38. Soriano-Maldonado A, Carrera-Ruiz Á, Díez-Fernández DM, et al. Effects of a 12-week resistance and aerobic exer- 
cise program on muscular strength and quality of life in breast cancer survivors: Study protocol for the EFICAN randomized controlled trial. Medicine 2019; 98: e17625.

39. Hasenoehrl T, Keilani M, Palma S, Crevenna R. Resistance exercise and breast cancer related lymphedema - a systematic review update. Disabil Rehabil 2020; 42: 26-35.

40. Polikandrioti M, Panoutsopoulos G, Tsami A, et al. Assessment of quality of life and anxiety in heart failure outpatients. Arch Med Sci Atheroscler Dis 2019; 4: e38-46.

41. Polikandrioti M, Kalafatakis F, Koutelekos I, Kokoularis D. Fatigue in heart failure outpatients: levels, associated factors, and the impact on quality of life. Arch Med Sci Atheroscler Dis 2019; 4: e103-12.

42. Schmitz KH, Courneya KS, Matthews C, et al. American College of Sports Medicine roundtable on exercise guidelines for cancer survivors. Med Sci Sports Exerc 2010; 42: 1409-26.

43. Segal R, Evans W, Johnson D, et al. Structured exercise improves physical functioning in women with stages I and II breast cancer: results of a randomized controlled trial. J Clin Oncol 2001; 19: 657-65.

44. Werner RS, McCormick B, Petrek J, et al. Arm edema in conservatively managed breast cancer: obesity is a major predictive factor. Radiology 1991; 180: 177-84.

45. Galantino ML, Stout NL. Exercise interventions for upper limb dysfunction due to breast cancer treatment. Phys Ther 2013; 93: 1291-7. 